\title{
The Impact of Website Quality and Reputation on Purchasing Intention Towards Online Shopping
}

\author{
Shaifali Chauhan \\ Assistant Professor, Prestige Institute of Management, Gwalior \\ Dr. Richa Banerjee \\ Assistant Professor, Prestige Institute of Management, Gwalior \\ Dr. Subeer Banerjee \\ Director, Academic Guru, Gwalior
}

\begin{abstract}
In today's scenario online business becoming a strong industry and the consumers have become more rational in decision. Present study investigates about the Impact of website quality and website reputation on Purchase Intention towards online shopping, the sample size chosen was a representation of population from 3 cities Gwalior, Bhopal, Indore and the age group chosen was 18 years to 36 years of age. The individual respondent had been used and 210 respondents were selected to collect data. The results specified that the data is highly reliable with the different values as reported by Cronbach's Alpha test. Exploratory factor analysis was applied in which 2 factors emerged in website quality, 2 factors emerged in reputation and 2 factors emerged in purchase intention. The Regression analysis concluded and proved that there was a positive significant Impact of independent Variable i.e. website quality and website reputation on dependent variable i.e. purchase intention.
\end{abstract}

Keywords: Website Quality, Reputation, Purchase Intention, Consumer Behaviour, Online Shopping.

\section{Conceptual Framework}

In comparison to previous decades, Ecommerce becomes popular in Indian market. India ranks 2nd in the world based on of population, which specifies about many customer bases. In E-commerce business there is no face- to- face interaction between the customer and the company, the first interaction mode is website homepage. A company's website signifies the public face to the world. Websites are the first way to establish a contact between a company and their customers, with the help of official website a company can-built trust among unknown vendor and eventually impact purchasing behaviour of a customer, which is very important in E-Businesses therefore companies need to focus towards the quality and reputation to increase profitability. Jin et al, (2008) and Lwin and Williams (2008) supposed that the website quality and website reputation of online retailer which considered as an online source of information hence it acts as an important role to evaluate the previous responses of website user and behaviour of consumer for future prospect. Jin et al, (2008) and Lee and Shavitt (2006) said that the reputation of the website has positive association to predicts consumer behaviour and consumer attitude. Consumer's information about the internet and website influences the purchase intention towards the product (Norton, 2007).

\section{Website Quality}

Website quality is an important parameter for the companies to make a profitable and website user friendly, and consumers consider website that it provides reliable information, the website should be good in design and visible appearance it should be able to fulfil the user needs and expectation. A web quality model shows classification and measurement of web quality. The perception of customer about website quality is based on features in website that meet customer needs and impress him, improves his total experience of that website. The multiple dimension of website quality can be categorised as security, enjoyment, information quality, ease of use and service quality. The quality of information offered by various brand on online shopping website are also an important factor to improve website quality. It reveals that 
information quality has the highest influence on consumer satisfaction among all website's quality dimensions.

\section{Website Reputation}

Website reputation is the reputation of a company, person, product, services or any other element of the internet and digital platforms. The website reputation is imparted by the content where an organization distributes, and also identified the reaction of end interaction with web users, activity on social networks etc. Reputations and brand are often superficial and vague when their role is being discussed in the context of web user trust. In empirical studies the meaning of reputations is often left to the interpretation of the respondent by simply asking for an estimation whether the firm is a good/bad reputation.

\section{Purchase Intention}

The willingness of a customer to buy a certain products or services is known as purchase intention. Purchase intention is a dependent variable which depends on several external and internal factors such as outcome expectations, aspirational value, recommendation, emotional association towards product and services. Purchase intention is one of the most favourable factors for the marketer that can certify for long run business. To analyse the chain reaction of consumer is closely connected with its purchasing intention among potential customers for successful business. Consumer purchasing intention is consider as an assumption of their actual behaviour. It is very important for business to understand the purchasing intention to their customer. The consumers plan to purchase those product and services which are expressed by a cognitive, it is define as purchasing intentions. The customer satisfaction has been formed to make a relationship between firms perceived quality to customer purchasing intention.

\section{Review of Literature}

Abbaspour Bagher, (2018) conducted research on 367 customers to examine the impact of website quality, customer emotion and electronic customer satisfaction on electronic loyalty of customer. SMARTPLS software was applied to analyse the responses. The research found that there was a positive significant impact of website quality, customer emotion and electronic customer satisfaction on electronic loyalty of customer and structural equations showed that the proposed model had relatively good fit with the data which was collected by the researcher.

Hamid Muhammad (2017) identified about the Effect of Website Reputation and Website Quality on Consumer Emotions, and Purchase Intention, 200 respondents filled the questioner. The researcher found that website reputation and website quality have a positive impact on consumers emotions, and the positive impact of emotions lead to the optimistic purchase intention. Similarly, Kim Jiyoung (2013) conducted research on 219respondentsfrom a large Midwestern university through online survey and Structural equation modeling (SEM) was used for data analyses researcher confirmed the relationship among the variable's website reputation, website quality, online consumers emotion, perceived risk and purchase intention. The study indicated that Reputation had a significant impact on consumers' emotion and on the other hand there is no significant impact on perceived risk. website quality had no significant impact on perceived risk and significant impact on consumer emotion, Perceived risk had a negative significant impact on both consumers' emotion, and perceived risk, consumer emotions had a positive significant impact on purchase intention.

Wang liang(2015) observed about the impact of hotel website quality on online booking intention. A research model that integrated in paper were hotel website quality, eTrust, and online booking intentions was analysed. The researcher found that hotel website quality positive significance on eTrust which then also facilitates the strong relationship between website quality and consumers' online booking intentions. Hence there was a significant impact of hotel website quality on online booking intention

Lee and lin (2005) examined that customer perception of online service quality had significant relationship with customer satisfaction and purchase intention. Online retailers are determined to fulfil every consumer needs due to intense competitive online market. Moreover, Luser, Zornoza and Tena (2001), also prove that customer satisfaction played a critical mediator role 
between service quality and purchase intention.

Hsu, Chang and Chen (2012) Conducted a research on "The impact of website quality on customer satisfaction and purchase intention towards perceived playfulness and perceived flow as mediator". The researcher found that website quality has positive relationship among the variables (customer's perceived playfulness and perceived flow) and also affect the dependent variables. Hence, this research found that the service quality play vital role than information quality and system quality have positive relationship in influencing customer satisfaction.

Jeon Myunghee Mindy (2017) investigated among the website quality, customers' perceived service quality, their satisfaction, return intention and loyalty towards lodging industry. confirmatory factor analysis and a parameter estimate analysis using structural equation modelling are used to analyse the collected data. The result found that the evolution of the loyalty proceeds in a linear fashion on a lodging website. And also identified the mediation effects of customer satisfaction and return intention are spotted. On the other hand, moderation effects of gender were also spotted as a positive relationship among website service quality and consequences of website service quality.

Kotha et al, (2001) observed that the reputations are an important risk-reducing mechanism in business environment. Researcher analysed that consumers are more likely to buy from an online retailer with better online reputations. Reputations allows consumer to anticipate the future behaviour of the company. (Walsh, Bartikowski and Beatty, 2014) also identified a positive reputation signals a high levels of website trustworthiness and a low level of risk, therefore, in context involving greater risk in selection, consumers rely more on firm reputation to make purchase decisions. Similarly (Mitchell and Vincent-Wayne, 1999) suggested that the reputation affects cognitive perceptions of quality and stimulate trust. (Monrman, Zaltman and Deshpande, 1992) explained a reputation in an indicator of trustworthiness and reliability. The concept that reputation increases the consumer trust towards the website has been positively confirmed in relation towards electronics travel services (de Ruyter et al, 2003). Likely (Akdeniz, Calantone and Vonrhees, 2013) Identified a positive a reputation is difficult, expensive and time - consuming process that requires a great deal of consistent relationshipenhancing behaviour on the part of the website towards their consumers. Consumers generally believe that websites who have established a positive reputation will be reluctant to risk their reputation by purchasing short-term gain at the expenses of their customers.

\section{Research Conceptual Model}

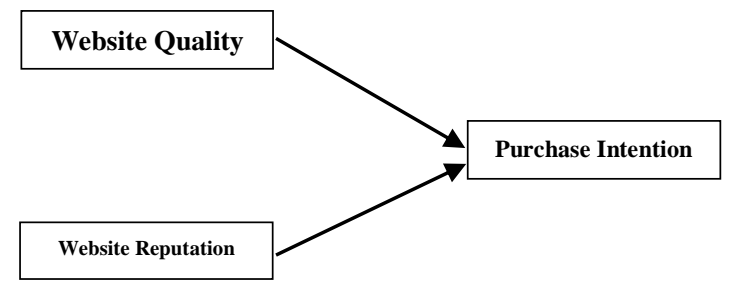

\section{Objectives:}

- To find out the underlying factors of website quality, reputation and purchase intention

- To identify the impact of website quality on purchase intention in online shopping.

- To identify the impact of website reputations on purchase in online shopping.

\section{Hypothesis}

H1: There is a significant impact of website quality on purchase intention in online shopping.

$\mathrm{H} 2$ : There is a significant impact of website reputations on purchase intention in online shopping.

\section{Research Methodology}

The study was empirical in nature and conducted to know the effect of website quality and reputations on purchase intention in online shopping.

POPULATION: Population included different age group 18 to 36 There are more active in seeking and buying both cognitive and affective products than younger and older generation.

\section{SAMPLE SIZE: 210 respondents}

Sample Elements: Individual respondent will be the sample element. 
Sample Techniques: Non probability purposive sampling technique will be used to select the sample.

\section{Tools for Data Collection:}

Standardized questionnaire of website quality and reputation were used which was formed by (Hamid Muhammad 2017) and purchase intention statement were used which was formed by (Kim and Lennon, 2008), for evaluating the effect of website quality and reputations on purchase intention in online shopping.

\section{Tooles for Data Analysis:}

- Cronbach's alpha method of reliability was used to check the consistency of questionnaire.

- Exploratory Factor Analysis was used to find out the underlying factors of website quality, reputation and purchase intention.

- Regression test was used to measure the Impact of independent variable on dependent variable.

\section{DATA ANALYSIS}

Reliability Statistics

\begin{tabular}{|c|c|c|c|c|}
\hline $\begin{array}{c}\text { S. } \\
\text { No. }\end{array}$ & $\begin{array}{c}\text { Variable } \\
\text { Name }\end{array}$ & $\begin{array}{c}\text { Cronbach's } \\
\text { Alpha }\end{array}$ & $\begin{array}{c}\text { Cronbach's } \\
\text { Alpha Based } \\
\text { on Standa- } \\
\text { rdized Items }\end{array}$ & $\begin{array}{c}\text { N of } \\
\text { Items }\end{array}$ \\
\hline 1 & $\begin{array}{c}\text { Website } \\
\text { Quality }\end{array}$ & .938 & .938 & 15 \\
\hline 2 & Reputation & .777 & .779 & 9 \\
\hline 3 & $\begin{array}{c}\text { Purchase } \\
\text { intention }\end{array}$ & .759 & .759 & 9 \\
\hline
\end{tabular}

The table is showing the reliability values of the questionnaires. Reliability of individual variable questionnaire was checked. The reliability test revealed Cronbach's Alpha value which is more than the standardized value (.7). It is considered that reliability of all measures was adequate. So, the statement in the questionnaire was treated as reliable statements

\section{Factor Analysis \\ Website Quality}

The raw scores of 15 items were subjected to factor analysis to find out the factors that contribute towards website quality. After factor analysis 2 factors were identified.

\section{KMO and Bartlett's Test}

\begin{tabular}{|c|c|c|}
\hline \multicolumn{2}{|c|}{$\begin{array}{c}\text { Kaiser-Meyer-Olkin Measure of } \\
\text { Sampling Adequacy. }\end{array}$} & .944 \\
\hline $\begin{array}{c}\text { Bartlett's } \\
\text { Test of } \\
\text { Sphericity }\end{array}$ & Approx. Chi-Square & 1936.273 \\
\cline { 2 - 3 } & Df & 105 \\
\cline { 2 - 3 } & Sig. & .000 \\
\hline
\end{tabular}

If $\mathrm{KMO}$ value is more than 0.6 then it considered as good value and the table is showing that the KMO value is 0.944 which means the sample that we have taken for factor analysis is acceptable. The chi square value (1936.273) is also significant at 0.000 level of significance.

\begin{tabular}{|c|c|c|c|c|}
\hline \multirow{2}{*}{$\begin{array}{l}\text { Factor } \\
\text { Name }\end{array}$} & \multicolumn{2}{|c|}{ Eigen value } & \multirow{2}{*}{ Variable coverage } & \multirow{2}{*}{ Loading } \\
\hline & Total & \%variance & & \\
\hline \multirow{14}{*}{$\begin{array}{l}\text { Website } \\
\text { Design }\end{array}$} & \multirow[t]{14}{*}{8.310} & \multirow[t]{14}{*}{55.402} & I feel my privacy is protected on this website. & .805 \\
\hline & & & The website provides depth information. & .799 \\
\hline & & & I believe that this website takes good care of its customers. & .794 \\
\hline & & & I received after purchase was what I expected. & .787 \\
\hline & & & The language used in this website is clear to me. & .786 \\
\hline & & & It is easy and quick to complete transaction on this website. & .781 \\
\hline & & & The website is well-designed in order not to waste of time. & .769 \\
\hline & & & The website is of high quality. & .769 \\
\hline & & & The product is delivered on time by the company. & .768 \\
\hline & & & I consider this website user- friendly. & .765 \\
\hline & & & $\begin{array}{l}\text { The company is willing and ready to respond to customer } \\
\text { inquiries promptly. }\end{array}$ & .764 \\
\hline & & & I feel safe in my transaction with this website. & .747 \\
\hline & & & I will consider this website to be the first choice for myself. & .734 \\
\hline & & & The quality of website products is extremely high. & .711 \\
\hline Reliability & 1.084 & 7.229 & $\begin{array}{l}\text { It is difficult to judge quality of product/ services on this } \\
\text { website. }\end{array}$ & .969 \\
\hline
\end{tabular}




\section{Reputation}

The raw scores of 9 items were subjected to factor analysis to find out the factors that contribute towards reputation. After factor analysis 2 factors were identified.

KMO and Bartlett's Test

\begin{tabular}{|c|c|c|}
\hline \multicolumn{2}{|c|}{$\begin{array}{c}\text { Kaiser-Meyer-Olkin Measure of } \\
\text { Sampling Adequacy. }\end{array}$} & .834 \\
\hline \multirow{3}{*}{$\begin{array}{c}\text { Bartlett's Test } \\
\text { of Sphericity }\end{array}$} & $\begin{array}{c}\text { Approx. Chi- } \\
\text { Square }\end{array}$ & 358.331 \\
\cline { 2 - 3 } & Df & 36 \\
\cline { 2 - 3 } & Sig. & .000 \\
\hline
\end{tabular}

If $\mathrm{KMO}$ value is more than 0.6 then it considered as good value and the table is showing that the $\mathrm{KMO}$ value is 0.834 which means the sample that we have taken for factor analysis is acceptable. The chi square value (358.331) is also significant at 0.000 level of significance.

\section{Purchase Intention}

The raw scores of 9 items were subjected to factor analysis to find out the factors that contribute towards purchase intention. After factor analysis 2 factors were identified.

KMO and Bartlett's Test

\begin{tabular}{|c|c|c|}
\hline \multicolumn{2}{|c|}{$\begin{array}{c}\text { Kaiser-Meyer-Olkin Measure of } \\
\text { Sampling Adequacy. }\end{array}$} & .847 \\
\hline \multirow{3}{*}{$\begin{array}{c}\text { Bartlett's Test } \\
\text { of Sphericity }\end{array}$} & $\begin{array}{c}\text { Approx. Chi- } \\
\text { Square }\end{array}$ & 309.589 \\
\cline { 2 - 3 } & Df & 36 \\
\cline { 2 - 3 } & Sig. & .000 \\
\hline
\end{tabular}

If $\mathrm{KMO}$ value is more than 0.6 then it considered as good value and the table is showing that the $\mathrm{KMO}$ value is 0.847 which means the sample that we have taken for factor analysis is acceptable. The chi square value (309.589) is also significant at 0.000 level of significance.

\begin{tabular}{|c|c|c|c|c|}
\hline \multirow[t]{2}{*}{ Factor Name } & \multicolumn{2}{|c|}{ Eigen value } & \multirow[t]{2}{*}{ Variable coverage } & \multirow[t]{2}{*}{ Loading } \\
\hline & Total & \%variance & & \\
\hline \multirow[t]{6}{*}{ Reputation } & \multirow[t]{6}{*}{2.605} & \multirow[t]{6}{*}{28.941} & $\begin{array}{l}\text { Overall, I am satisfied with specific experience with the } \\
\text { website. }\end{array}$ & .796 \\
\hline & & & $\begin{array}{l}\text { We preferred a product more and more if the reputation of } \\
\text { the website is good. }\end{array}$ & .764 \\
\hline & & & This website is a large company that everyone recognizes. & .630 \\
\hline & & & This website is well-known. & .594 \\
\hline & & & $\begin{array}{l}\text { I referred those online websites on which reputed brand are } \\
\text { associated. }\end{array}$ & .543 \\
\hline & & & I only referred website which is well known. & .458 \\
\hline \multirow{3}{*}{$\begin{array}{l}\text { Perceived } \\
\text { risk }\end{array}$} & \multirow[t]{3}{*}{1.747} & \multirow[t]{3}{*}{19.411} & The website provides high quality of product. & .832 \\
\hline & & & $\begin{array}{l}\text { I buy a product; it is related to a reputable and famous } \\
\text { retailer. }\end{array}$ & .587 \\
\hline & & & The brand of the website is considered as high quality. & .553 \\
\hline
\end{tabular}

\begin{tabular}{|c|c|c|c|c|}
\hline \multirow[t]{2}{*}{ Factor Name } & \multicolumn{2}{|c|}{ Eigen value } & \multirow{2}{*}{ Variable coverage } & \multirow{2}{*}{ Loading } \\
\hline & Total & \%variance & & \\
\hline \multirow{3}{*}{$\begin{array}{l}\text { Purchase } \\
\text { behaviour }\end{array}$} & \multirow[t]{3}{*}{2.169} & \multirow[t]{3}{*}{24.099} & I am likely to recommend online shopping to my friends. & .713 \\
\hline & & & $\begin{array}{l}\text { I will buy an item from this website if I find something } \\
\text { that I like. }\end{array}$ & .684 \\
\hline & & & $\begin{array}{l}\text { I will revisit this website to discover new products and } \\
\text { get shopping ideas in the future. }\end{array}$ & .666 \\
\hline \multirow[t]{6}{*}{ Security } & \multirow[t]{6}{*}{1.987} & \multirow[t]{6}{*}{22.074} & $\begin{array}{l}\text { I will be willing to provide my credit card details when } \\
\text { purchasing from an online retailer. }\end{array}$ & .741 \\
\hline & & & I intend to buy through internet. & .587 \\
\hline & & & I will buy an item I viewed at this website in near future. & .534 \\
\hline & & & $\begin{array}{l}\text { It is probable that I would buy through internet in the } \\
\text { future. }\end{array}$ & .499 \\
\hline & & & $\begin{array}{l}\text { I will visit this website when I want to buy certain items } \\
\text { in near future. }\end{array}$ & .493 \\
\hline & & & I strongly recommend others should shop from amazon. & .477 \\
\hline
\end{tabular}




\section{Description of Factors}

The raw scores of 33 items were subjected to factor analysis to find out the factors that contribute towards website quality, reputation and Purchase Intention. After factor analysis, 6 factors were identified.

Website Design: This factor has emerged as the most important determinant of website quality with total variance of $55.402 \%$. it includes some statements such as I feel my privacy is protected on this website .805 , The website provides depth information .799, I believe that this website takes good care of its customers .794, I received after purchase was what I expected .787, The language used in this website is clear to me .786, It is easy and quick to complete transaction on this website .781, The website is well-designed in order not to waste of time .769, The website is of high quality .769, The product is delivered on time by the company .768, I consider this website user- friendly .765, The company is willing and ready to respond to customer inquiries promptly .764, I feel safe in my transaction with this website .747, I will consider this website to be the first choice for myself .734, The quality of website products is extremely high .711

Reliability: This factor has emerged as the most important determinant of website quality with total variance of $7.229 \%$. It includes one statement such as It is difficult to judge quality of product/ services on this website .969

Reputation: This factor has emerged as the most important determinant of reputation with total variance of $28.941 \%$. It includes some statements such as Overall, I am satisfied
Perceived risk: This factor has emerged as the most important determinant of reputation with total variance of $19.411 \%$. It includes some statements such as the website provides high quality of product .832, I buy a product; it is related to a reputable and famous retailer .587 , The brand of the website is considered as high quality .553

Purchase behaviour: This factor has emerged as the most important determinant of purchase intention with total variance of $24.099 \%$. It includes some statements such as I am likely to recommend online shopping to my friends .713, I will buy an item from this website if I find something that I like .684, I will revisit this website to discover new products and get shopping ideas in the future .666

Security: This factor has emerged as the most important determinant of purchase intention with total variance of $22.074 \%$. It includes some statements such as I will be willing to provide my credit card details when purchasing from an online retailer .741, I intend to buy through internet .587, I will buy an item I viewed at this website in near future .534 , It is probable that I would buy through internet in the future .499 , I will visit this website when I want to buy certain items in near future .493, I strongly recommend others should shop from amazon .477

\section{Regression Analysis}

Table gives the model summary of regression analysis of the three variables that is Website Quality, Reputation, Purchase intention. The $r$ value explains the correlation coefficient

\begin{tabular}{|c|c|c|c|c|c|c|c|c|c|c|}
\hline \multicolumn{11}{|c|}{ Model Summary b } \\
\hline \multirow[b]{2}{*}{ Model } & \multirow[b]{2}{*}{$\mathrm{R}$} & \multirow[b]{2}{*}{$\begin{array}{c}\mathrm{R} \\
\text { Square }\end{array}$} & \multirow[b]{2}{*}{$\begin{array}{l}\text { Adjusted } \\
\text { R Square }\end{array}$} & \multirow{2}{*}{$\begin{array}{c}\text { Std. } \\
\text { Error of } \\
\text { the } \\
\text { Estimate }\end{array}$} & \multicolumn{5}{|c|}{ Change Statistics } & \multirow[b]{2}{*}{$\begin{array}{l}\text { Durbin- } \\
\text { Watson }\end{array}$} \\
\hline & & & & & $\begin{array}{c}\mathrm{R} \\
\text { Square } \\
\text { Change }\end{array}$ & $\begin{array}{c}\mathrm{F} \\
\text { Change }\end{array}$ & df1 & df2 & $\begin{array}{l}\text { Sig. F } \\
\text { Change }\end{array}$ & \\
\hline \begin{tabular}{l|l} 
dimension 0 & 1 \\
\end{tabular} & $1 \quad .834^{\mathrm{a}}$ & .695 & .692 & 3.41244 & .695 & 229.535 & 2 & 201 & .000 & 1.746 \\
\hline \multicolumn{11}{|c|}{ a. Predictors: (Constant), Website reputation, website quality } \\
\hline \multicolumn{11}{|c|}{ b. Dependent Variable: Purchase intention } \\
\hline
\end{tabular}

with specific experience with the website .796, We preferred a product more and more if the reputation of the website is good .764, This website is a large company that everyone recognizes .630, This website is well-known .594 , I referred those online websites on which reputed brand are associated .543, I only referred website which is well known .458 among three variables. the value of $r$ square helps in predicting the explained variance in dependent variable (purchase intention) with the help of website quality and reputation. The tables show that $69.2 \%$ variance in purchase intention can be explained with the help of website quality and reputation. 


\begin{tabular}{|c|c|c|c|c|c|c|}
\hline \multicolumn{7}{|c|}{ ANOVA $^{\mathbf{b}}$} \\
\hline \multicolumn{2}{|c|}{ Model } & $\begin{array}{c}\text { Sum of } \\
\text { Square } \\
\text { s }\end{array}$ & Df & $\begin{array}{c}\text { Mean } \\
\text { Square }\end{array}$ & F & Sig. \\
\hline \multirow{2}{*}{1} & $\begin{array}{c}\text { Regressio } \\
\mathrm{n}\end{array}$ & $\begin{array}{c}5345.74 \\
5\end{array}$ & 2 & $\begin{array}{c}2672.87 \\
2\end{array}$ & $\begin{array}{c}229.53 \\
5\end{array}$ & $\begin{array}{c}.000 \\
\text { a }\end{array}$ \\
\cline { 2 - 7 } & Residual & $\begin{array}{c}2340.58 \\
8\end{array}$ & 20 & 11.645 & & \\
& Total & 7686.33 & 20 & & & \\
& 3 & 3 & & & \\
\hline
\end{tabular}

a. Predictors: (Constant), Website Quality, Reputation

b. Dependent Variable: Purchase Intention

The value of $F$ is 229.535 and which is significant at 0.000 level of significance, this signifies that the model of the study is a good fit.

\begin{tabular}{|c|c|c|c|c|c|}
\hline \multicolumn{6}{|c|}{ COEFFICIENTSA } \\
\hline Model & \multicolumn{2}{|c|}{$\begin{array}{l}\text { Unstandardi } \\
\text { zed } \\
\text { Coefficients }\end{array}$} & $\begin{array}{l}\text { Standardi } \\
\text { zed } \\
\text { Coefficien } \\
\text { ts }\end{array}$ & & \\
\hline & B & $\begin{array}{l}\text { Std. } \\
\text { Erro } \\
r\end{array}$ & Beta & $\mathrm{T}$ & $\begin{array}{l}\mathrm{Si} \\
\mathrm{g} .\end{array}$ \\
\hline (Constant) & 6.806 & $\begin{array}{c}1.23 \\
5\end{array}$ & & $\begin{array}{l}5.5 \\
11\end{array}$ & $\begin{array}{c}.00 \\
0\end{array}$ \\
\hline $\begin{array}{l}\text { Website } \\
\text { Quality }\end{array}$ & .240 & .033 & .485 & $\begin{array}{l}7.3 \\
65\end{array}$ & $\begin{array}{c}.00 \\
0\end{array}$ \\
\hline $\begin{array}{ll}\text { 2. } & \begin{array}{l}\text { Reputati } \\
\text { on }\end{array}\end{array}$ & .372 & .063 & .392 & $\begin{array}{l}5.9 \\
45\end{array}$ & $\begin{array}{c}.00 \\
0\end{array}$ \\
\hline
\end{tabular}

The table explains that overall impact of Website Quality and reputation on purchase intention. The beta value of website quality is .485 , beta value of reputation is .392 and $t$ value of website quality is 7.365 at $0.000 \%, \mathrm{t}$ value of reputation is 5.945 at $0.00 \%$ level of significance. Hence, we can conclude that website quality and reputation have significant impact on the purchase intention and hence the null hypothesis is rejected and there is an impact of website quality and reputation on purchase intention

\section{Conclusion}

Consumer make purchase after collecting full information related to product and company. To collect such information consumer focuses on website quality and reputation. Therefore, from the above analysis, we conclude that website quality and reputation have significant impact on the purchase intention and hence the null hypothesis is rejected. Similarly, Lee and Lin (2005) identified that information provided by a company website (online store) have significant impact on consumer intention and customer satisfaction. Sun et al. (2015) found that the impact of beliefs towards e-service quality on customer satisfaction therefore identified that there is a significant impact on purchase intention. Exploratory factor analysis was applied in which 2 factors emerged in website quality, 2 factors emerged in reputation and 2 factors emerged in purchase intention. Hence this study is beneficial for future research

\section{References:}

- Abbaspour Bagher, Aziz Abtin, Asghar JoukarAbnavi, Ali Akbar Mirzaee (2018) the impact of website quality, customer emotion and electronic customer satisfaction on electronic loyalty of customer, Herald NAMSCA Volume 4

- Canadian centre of science and education. (2015, july14). The effect of website quality on purchase intention in online shopping, Journal of research in business and management, 10(10), 158-170.

- Chandaram M, Ramanin A.V. The effect of website quality on purchasing intention in online shopping, Journal of electrical engineering \& computer science, 4(1), 224230.

- Dan Su\& Xu Huang, (2011, Jan). Effect Online shopping Intention of Undergraduated Consumer, Journal of International business research, 4(1), 86-92.

- Elsevier B.V. (2015). The impact of website quality on online purchase intention: A Web qual model approach, journal of research in computer science, 72(2015), 382-389

- GangulyB.et al. (2010). The effects of website design on purchase intention in online shopping, Journal of research in Electronic Business, 8(4/5), 302-330.

- Hsu, Chia-Lin \& Chang, Kuo-Chien\& Chen, Mu-Chen. (2012). The impact of website quality on customer satisfaction and purchase intention: Perceived playfulness and perceived flow as mediators. Information Systems and eBusiness Management. 10. 10.1007/s10257-011-0181-5.

- Jeon Myunghee Mindy, MiyoungJeong (2017) consumers perceived website 
service quality and its effects on e-loyalty , International Journal of contemporary hospitality Management ISSN:0959- 6119

- Kim, J., \& Lennon, S. J. (2013). Effects of reputation and website quality on online consumers' emotion, perceived risk and purchase intention: Based on the stimulusorganism-response model. Journal of Research in Interactive Marketing, 7(1), 33-56.

- Khalid Ismail, Ishak Nawawi (2014).Effect of Purchase intention on actual purchase behaviour, Journal of Research in Integrative Business and Economics, 3(2), 378-397.

- Lukas Vartik (2015, June 22-24). The effect of online website reputation on organizational Operating, Journal of University of Zilina, Zilina, Slovak Reputation,-270-275.

- Llusar, J. C. B., Zornoza, C. C, \& Tena, A. B. E. (2001). Measuring the relationship between firm perceived quality and customer satisfaction and its influence on purchase intentions. Total Quality Management, 12(6), 719-734.

- Mohammad Naeem Raj Muhammad Kamran Saeed Ammad (2015).Effect of consumer brand purchase intention in online shopping, Journal of research in marketing and consumer research, 15, 113117.

- Sharron J.Lennon. (2015, feb06)."Effects Consumers' and purchase intention: Based on the stimulus-organism-response model, Journal of research in interactive marketing,(7).(1),33-56.

- S.Einwiller.(2001). The effect of website reputation on purchase intention in online shopping, Journal of research in symposium on Emerging Electronic Markets, 23, 395-412.

- Sa Diego.(2016). The effect of website reputation on purchase intention in online shopping, Journal of research in Information System.

- Thomas rani mary, (2018, Jan 1).Influence of Online Website Cues on Purchasing Intention, Indian Journal of Commerce \& Management Studies, 9(1),13-23

- Wang, Qiuzhen and Dai, Yiling (2013. Effect of Online Product presentation and Reputation on Consumer Purchasing Intention, Journal of AIS Electronic Library(AISeL), 31(3), 475-500.

- Wang liang, Rob Law (2015) the impact of hotel website quality on online booking intention: eTrust as a mediator, International Journal of hospitality Management, Volume 47, Pages 108-115. 